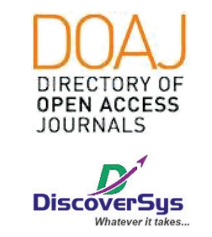

Published by DiscoverSys

\section{Perbedaan jenis kuman pada pasien Diabetes Mellitus Tipe-2 (DM-2) dengan infeksi saluran kemih dan bakteriuria asimtomatik di RSUP H. Adam Malik, Medan, Indonesia}

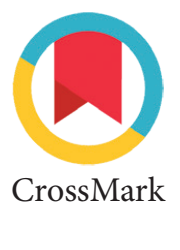

\author{
Deby Novayanti, ${ }^{*}$ Ricke Loesnihari, ${ }^{2}$ Muzahar ${ }^{2}$
}

\title{
ABSTRACT
}

Background: Patients with Diabetes Mellitus Type-2 (DM-2) have a high probability of suffering from urinary tract infections (UTIS) and asymptomatic bacteriuria $(A B) . A B$ is the presence of significant bacteriuria $>10^{5} \mathrm{cfu} / \mathrm{ml}$ in urine cultures without clinical symptoms (asymptomatic). This study aims to find out the different types of the pathogen in DM-2 patients with urinary tract infections and bacteriuria asymptomatic at H. Adam Malik Hospital, Medan, Indonesia.

Methods: A total of $18 \mathrm{DM}-2$ patients with UTIs and 18 patients with $A B$ who met the criteria were included in this study from $\mathrm{H}$. Adam Malik Hospital, Medan, Indonesia. Fasting blood glucose and blood glucose levels in 2 hours postprandial were examined. The middle portion of urine sample using a sterile container was conducted for urinalysis test using dipstick (Combur10 Test M, Roche Mannheim, Germany) and a Cobas U 411 ROCHE urine analyzer. Urine leukocytes were evaluated using leukocyte esterase. The urine culture for identification of bacterial and antibiotic sensitivity tests was conducted if leukocytes count $>5$ / LPB. Data were analyzed using SPSS version 17 for Windows.

Results: Most of the DM-2 respondents were females in both Urinary Tract Infection (UTI) group (77.8\%) and Asymptomatic Bacteriuria (AB) group (88.9\%). The age group of 39-50 years was predominant in the UTIs group (50.0\%) compared with AB group in age 51-62 years old group (44.4\%). Data were normally distributed between types of bacterial infection on both groups ( $p=0.945)$. However, based on the sensitivity and resistance of antibiotics, no significant difference was found between both groups ( $P>0.05)$ except for cefixime $(p=0.018)$ from the Chi-square test.

Conclusion: There were no differences in the types of pathogen in UTIs and $A B$ among DM-2 patients. Besides, no significant difference for bacterial sensitivity and resistance found between groups except in cefixime.

Keywords: Pathogens, UTIs, Asymptomatic Bacteriuria, DM-2, Difference

Cite This Article: Novayanti, D., Loesnihari, R., Muzahar. 2020. Perbedaan jenis kuman pada pasien Diabetes Mellitus Tipe-2 (DM-2) dengan infeksi saluran kemih dan bakteriuria asimtomatik di RSUP H. Adam Malik, Medan, Indonesia. Intisari Sains Medis 11(1): 333-339. D0I: 10.15562/ ism.v11i1.569

\section{ABSTRAK}

Latar Belakang: Pasien Diabetes Mellitus Tipe-2 (DM-2) memiliki kemungkinan tinggi menderita Infeksi Saluran Kemih (ISK) dan Bakteriuria Asimptomatik (BAS). BAS adalah adanya bakteriuria yang signifikan $>10^{5}$ cfu/ml dalam kultur urin tanpa gejala klinis (asimptomatik). Penelitian ini bertujuan untuk mengetahui berbagai jenis patogen pada pasien DM-2 dengan infeksi saluran kemih dan bakteriuria asimptomatik di Rumah Sakit H. Adam Malik, Medan, Indonesia.

Metode: Sebanyak 18 pasien DM-2 dengan ISK dan 18 pasien dengan BA yang memenuhi kriteria dimasukkan dalam penelitian ini dari Rumah Sakit H. Adam Malik, Medan, Indonesia. Glukosa darah puasa dan kadar glukosa darah dalam 2 jam post-prandial diperiksa. Bagian tengah sampel urin menggunakan wadah steril diambil untuk menjalani tes urinalisis menggunakan dipstick (Combur10 Test M, Roche Mannheim, Jerman) dan alat analisis urin Cobas U 411 ROCHE. Leukosit urin dievaluasi menggunakan leukosit esterase. Kultur urin untuk identifikasi tes sensitivitas bakteri dan antibiotik dilakukan jika jumlah leukosit > 5/ LPB. Data dianalisis menggunakan SPSS versi 17 untuk Windows.

Hasil: Sebagian besar responden DM-2 adalah perempuan dalam kelompok Infeksi Saluran Kemih (ISK) (77,8\%) dan kelompok Bakteriuria Asimtomatik (BAS) (88,9\%). Kelompok usia 39-50 tahun dominan pada kelompok ISK (50,0\%) dibandingkan dengan BA pada kelompok usia 51-62 tahun (44,4\%). Data terdistribusi secara normal terhadap jenis infeksi bakteri pada kedua kelompok ( $p=0,945$ ). Namun, berdasarkan sensitivitas dan resistensi antibiotik, tidak ada perbedaan bermakna yang ditemukan antara kedua kelompok $(P>0,05)$ kecuali untuk sefiksim $(p=0,018)$ dari uji Chi-square.

Kesimpulan: Tidak ada perbedaan dalam jenis patogen pada ISK dan AB pada pasien DM-2. Selain itu, tidak ada perbedaan bermakna untuk sensitivitas dan resistensi bakteri yang ditemukan antara kelompok kecuali pada sefiksim. 


\section{PENDAHULUAN}

Pasien dengan Diabetes Melitus tipe-2 (DM-2) mempunyai kemungkinan yang tinggi untuk menderita Infeksi Saluran Kemih (ISK) dan bakteriuria asimtomatik. ${ }^{1}$ DM-2 memiliki efek jangka panjang pada kejadian ISK dan telah dilaporkan sekitar tiga sampai empat kali lebih tinggi pada pasien DM-2 dibandingkan dengan pasien non DM-2. ${ }^{1}$ Adanya genangan urin statis akibat disfungsi kandung kemih yang berkontraksi dengan buruk sebagai media yang menguntungkan untuk pertumbuhan bakteri, urin pada pasien hiperglikemik mendorong pertumbuhan bakteri dan kolonisasi yang cepat. ${ }^{2}$

Badan Kesehatan Dunia (WHO) memprediksi adanya peningkatan jumlah penyandang DM-2 yang cukup menjadi salah satu ancaman kesehatan global. ${ }^{3}$ DM-2 merupakan penyakit metabolik yang diderita 16 juta orang di Amerika Serikat yang berhubungan dengan peningkatan risiko terjadinya ISK. ${ }^{4}$ DM-2 menyebabkan beberapa kelainan di dalam sistem pertahanan tubuh yang memungkinkan peningkatan risiko tinggi terkena infeksi yang lainnya. Adapun kelainan tersebut termasuk kelainan imunologi seperti kegagalan migrasi, intracellular killing, pagositosis dan kemotaksis pada leukosit polymorphonuclear, serta melemahkan mekanisme pertahanan alamiah lokal, baik intrinsik maupun ekstrinsik, sehingga pasien DM-2 lebih rentan terhadap infeksi. ${ }^{5}$ Konsentrasi glukosa yang tinggi didalam urin merupakan media yang baik untuk pertumbuhan mikroorganisme patogen. ${ }^{6}$

ISK merupakan masalah umum pada penderita DM, oleh karena itu penderita DM-2 mempunyai kemungkinan menderita ISK lebih tinggi dibandingkan dengan tidak menderita DM-2 dan juga menderita infeksi yang lebih berat, yang akan meningkatkan risiko untuk masuk rumah sakit sebagai pielonefritis dan mempunyai frekuensi yang lebih tinggi untuk terjadinya bakteriemia dan kerusakan kedua ginjal. ${ }^{7}$

ISK adalah istilah umum yang menunjukkan keberadaan mikroorganisme dalam urin yang tumbuh dan berkembangbiaknya kuman dalam saluran kemih yang mengakibatkan invasi serta inflamasi jaringan pada saluran kemih. ${ }^{8}$ Bakteriuria bermakna (significant bacteriuria): Bakteriuria bermakna menunjukkan pertumbuhan mikroorganisme (MO) murni lebih dari $10^{5}$ colony forming units $(\mathrm{cfu} / \mathrm{ml})$ pada biakan urin segar yang diambil dengan cara pancar tengah (fresh voided midstream urine). Bila urin didapatkan supra pubik, setiap ada tumbuh bakteri dianggap bakteriuria bermakna. Bakteriuria bermakna mungkin tanpa disertai presentasi klinis ISK dinamakan bakteriuria asimtomatik (covert bacteriuria). Sebaliknya bakteriuria bermakna disertai presentasi klinis ISK dinamakan bakteriuria bermakna simtomatik. ${ }^{9}$

Diagnosis ISK dibuat berdasarkan presentasi klinis, pemeriksaan fisik dan pemeriksaan penunjang. Pemeriksaan yang terpenting adalah biakan urin sebagai standar baku emas dimana dapat mendeteksi keberadaan pasien meskipun dalam keadaan tidak ada gejala (asimtomatik). ${ }^{10}$ Berkaitan dengan hal tersebut maka penelitian ini bertujuan untuk mengetahui perbedaan jenis kuman pada pasien Diabetes Mellitus Tipe-2 (DM-2) dengan infeksi saluran kemih dan bakteriuria asimtomatik di RSUP H. Adam Malik, Medan, Indonesia

\section{METODE}

Penelitian ini merupakan studi observasional analitik dengan metode potong lintang (cross-sectional) untuk mengetahui perbedaan jenis kuman pada pasien DM-2 dengan infeksi saluran kemih dan bakteriuria asimtomatik. Penelitian dilakukan di Laboratorium Patologi Klinik RSUP. H. Adam Malik Medan dimulai pada bulan Februari sampai April 2018.

Populasi penelitian adalah pasien DM-2 yang melakukan pemeriksaan kadar gula darah puasa dan 2 jam postprandialdi Laboratorium Patologi Klinik RSUP. H. Adam Malik Medan. Sedangkan sampel adalah populasi terjangkau yang memenuhi kriteria inklusi dimana mencakup: 1) Pasien DM-2 yang berobat ke Poli Endokrinologi RSUP. H. Adam Malik Medan; 2) Pasien dewasa (berusia > 18 tahun); dan 3) Pasien bersedia ikut dalam penelitian dan dibuktikan dengan menandatangani lembar persetujuan. Sedangkan kriteria eksklusi yang dipergunakan dalam penelitian ini adalah: 1) Pasien tidak bersedia ikut berpartisipasi dalam penelitian; 2) Pasien sudah mendapat terapi antibiotik; 3) Pasien sedang menstruasi; 4) Pasien menggunakan kateter urin; dan 5) Pasien hamil.

ISK adalah infeksi yang melibatkan bagian dari sistem urinari, termasuk uretra, kandung kemih, ureter dan ginjal serta dijumpainya bakteriuria bermakna dari pemeriksaan kultur urin dengan disertai gejala klinis. Bakteriuria asimtomatk adalah infeksi yang melibatkan bagian dari sistem urinari, termasuk uretra, kandung kemih, ureter dan ginjal serta dijumpainya bakteriuria bermakna dari pemeriksaan kultur urin tanpa disertai gejala klinis. Dikatakan bakteriuria bermakna bila ditemukan pertumbuhan mikroorganisme murni lebih dari $10^{5}$ colony forming units $(\mathrm{cfu} / \mathrm{ml})$ pada biakan urin segar yang diambil dengan cara pancar tengah (fresh voided midstream urine). Bila urin didapatkan supra pubik, setiap ada tumbuh bakteri dianggap bakteriuria bermakna. 
Bahan pemeriksaan laboratorium berupa darah untuk pemeriksaan kadar glukosa puasa dan kadar glukosa 2 jam postprandial dengan metode enzimatik glucose oxidase / hexokinase menggunakan alat Accu-check Performa dan sampel urin porsi tengah yang dikumpulkan dari pasien DM-2 dengan menggunakan wadah penampung urin yang steril untuk pemeriksaan urinalisis jumlah leukosit urin dan kultur urin. Adanya leukosit didalam urin dideteksi menggunakan dipstik (Combur ${ }^{10}$ Test M, Roche Mannheim, Germany) dan alat urine analyzer Cobas U 411 ROCHE dengan metode prinsip pemeriksaan leukosit esterase. Apabila didapati leukosit sedimen $>5 /$ LPB maka dilanjutkan dengan pemeriksaan kultur urin untuk identifikasi jenis kuman dan uji kepekaan antibiotik. Kultur urin menggunakan media Cysteine Lactose Electrolyte Deficient (CLED) agar. Setelah plate digores dengan urin tanpa disentrifus menggunakan ose steril (volume $10 \mu \mathrm{L}$ ) dengan goresan merata 2 arah, lalu diinkubasi pada suhu $37^{\circ} \mathrm{C}$ selama $24 \mathrm{jam}$. Hasil kultur dengan jumlah koloni $>10^{5} \mathrm{cfu} / \mathrm{ml}$, untuk satu jenis kuman dianggap signifikan bakteriuria. Pemeriksaan identifikasi jenis kuman menggunakan API $20 \mathrm{E}$ (Biomerieux ${ }^{\mathrm{R}}$ SA FRANCE) untuk identifikasi kuman Gram negatif. Tes katalase, tes koagulase, dan tes Manitol Salt Agar (MSA) untuk identifikasi kuman Gram positif. Tes kepekaan terhadap antibiotik dilakukan dengan metode difusi cakram (disk diffusion method) pada agar MullerHinton yang telah diinokulasi bakteri, dimana hasil interpretasinya adalah sensitif dan resisten. Antibiotik yang digunakan yaitu amikasin, amoksisilin-asam klavulanat, siprofloksasin, sefotaksim, seftriakson, doksisiklin, sefiksim, meropenem, sulbaktam-sefoperazon, tetrasiklin, dan ampisilin.

Seluruh data yang diperoleh kemudian ditabulasi dan dianalisis menggunakan piranti lunak SPSS versi 17 untuk Windows. Data ditampilkan dalam bentuk jumlah, persentase, normalitas, maupun nilai $\mathrm{p}$

\section{HASIL}

Penelitian ini melibatkan 36 orang dimana terbagi menjadi dua kelompok yaitu 18 orang merupakan pasien DM-2 dengan Infeksi Saluran Kemih (ISK) dan 18 orang merupakan pasien dengan DM-2 dengan Bakteriuria Asimtomatik (BAS) yang memenuhi kriteria inklusi dan eksklusi (Tabel 1).

Tabel 1 menunjukkan karakteristik sampel penelitian berupa jenis kelamin dan kelompok umur. Dari 18 pasien DM-2 dengan ISK ditemukan $14(77,8 \%)$ berjenis kelamin perempuan dan jenis kelamin laki-laki ditemukan sebanyak $4(22,2 \%)$.
Dari 18 pasien DM-2 dengan bakteriuria asimtomatik ditemukan $16(88,9 \%)$ berjenis kelamin perempuan dan jenis kelamin laki-laki ditemukan sebanyak 2 (11,1\%) (Tabel 1). ISK dan bakteriuria asimtomatik banyak diderita pasien perempuan dengan DM-2 daripada laki-laki dengan DM-2 (Tabel 1).

Hasil pada Tabel 1 juga menunjukkan bahwa pasien DM-2 dengan ISK yang termuda menderita penyakit adalah berusia 39 tahun dan tertua adalah berusia 74 tahun. Didapatkan bahwa kelompok umur pasien DM-2 dengan ISK yang paling banyak dijumpai pada kelompok umur 39 - 50 tahun yaitu sebanyak 9 orang $(50,0 \%)$, diikuti dengan kelompok umur 51 - 62 tahun sebanyak 5 orang $(27,8 \%)$ dan yang terendah pada kelompok umur 63 - 74 tahun sebanyak 4 orang $(22,2 \%)$ (Tabel 1). DM-2 dengan bakteriuria asimtomatik, paling banyak dijumpai pada kelompok umur 51 - 62 tahun yaitu sebanyak 8 orang $(44,4 \%)$, diikuti dengan kelompok umur 39 - 50 tahun dan kelompok umur 63 - 74 tahun masing-masing sebanyak 5 orang $(27,8 \%)$ (Tabel 1$)$.

Berdasarkan Tabel 1 diatas, dari 18 pasien DM-2 dengan ISK didapati jenis bakteri paling banyak tumbuh pada kultur urin adalah Escherichia coli 11 $(61,0 \%)$, diikuti Staphylococcus aureus $2(11,0 \%)$, Klebsiella pneumoniae 1 (5,6\%), Staphylococcus saprophyticus 1 (5,6\%), Serratia marcescens $1(5,6 \%)$, Serratia liquefaciens 1 (5,6\%), dan Citrobacter freundii 1 (5,6\%) (Tabel 1 dan Gambar 1). Sedangkan dari hasil kultur urin 18 pasien DM-2 dengan bakteriuria asimtomatik didapati bakteri yang tumbuh adalah Escherichia coli 3 (16,7\%), Klebsiella pneumoniae 3 (16,7\%), Staphylococcus aureus 3 (16,7\%), Streptococcus agalactiae 3 (16,7\%), Staphylococcus saprophyticus 2 (11,0\%), Staphylococcus epidermidis 2 (11,0\%), Serratia liquefaciens 1 (5,6\%), dan Enterobacter cloacae 1 (5,6\%) (Tabel 1 dan Gambar 1). Berdasarkan uji Kolmogorov-Smirnov didapatkan nilai p $>0,05$ yang menunjukkan bahwa data berdistribusi normal dengan tidak adanya perbedaan jenis kuman pada infeksi saluran kemih dan bakteriuria asimtomatik (Tabel 1).

Berdasarkan Tabel 2, uji sensitivitas terhadap kultur urin 18 pasien DM-2 dengan ISK, ditemukan bahwa tingkat sensitivitas meropenem dan cefoperazone adalah paling tinggi $100,0 \%(\mathrm{n}=18)$, diikuti dengan amikacin $94,4 \%(\mathrm{n}=17)$, dan amoxyclav $83,3 \%(n=15)$. Uji sensitivitas terhadap kultur urin 18 pasien DM-2 dengan bakteriuria asimtomatik, ditemukan bahwa tingkat sensitivitas amikacin dan meropenem adalah paling tinggi $100,0 \%(\mathrm{n}=18)$, diikuti amoxyclav dan cefoperazone $94,4 \%(\mathrm{n}=17)$ (Tabel 2).

Dari hasil kultur urin 18 pasien DM-2 dengan ISK dan 18 pasien DM-2 dengan bakteriuria 
Tabel 1 Karakteristik maupun pola penyebaran mikroorganisme pada pasien DM-2 dengan ISK dan BAS

\begin{tabular}{|c|c|c|c|c|c|}
\hline \multirow[b]{3}{*}{ Karakteristik } & \multicolumn{4}{|c|}{ Pasien DM-2 ( $\mathrm{N}=36)$} & \multirow[b]{3}{*}{$\mathbf{P}$} \\
\hline & \multicolumn{2}{|c|}{ ISK ( $N=18)$} & \multicolumn{2}{|c|}{ BAS $(N=18)$} & \\
\hline & $\mathbf{n}$ & $\%$ & $\mathbf{n}$ & $\%$ & \\
\hline \multicolumn{6}{|l|}{ Jenis kelamin } \\
\hline Laki-Laki & 4 & 22,2 & 2 & 11,1 & - \\
\hline Perempuan & 14 & 77,8 & 16 & 88,9 & \\
\hline \multicolumn{6}{|l|}{ Umur } \\
\hline 39-50 tahun & 9 & 50,0 & 5 & 27,8 & - \\
\hline 51-62 tahun & 5 & 27,8 & 8 & 44,4 & \\
\hline 63-74 tahun & 4 & 22,2 & 5 & 27,8 & \\
\hline \multicolumn{6}{|l|}{ Mikroorganisme } \\
\hline Escherichia coli & 11 & 61,0 & 3 & 16,7 & 0,945 \\
\hline Klebsiella pneumonia & 1 & 5,6 & 3 & 16,7 & \\
\hline Staphylococcus aureus & 2 & 11,0 & 3 & 16,7 & \\
\hline Staphylococcus saprophyticus & 1 & 5,6 & 2 & 11,0 & \\
\hline Serratia marcescens & 1 & 5,6 & 0 & 0,0 & \\
\hline Serratia liquefaciens & 1 & 5,6 & 1 & 5,6 & \\
\hline Citrobacter freundii & 1 & 5,6 & 0 & 0,0 & \\
\hline Streptococcus agalactiae & 0 & 0,0 & 3 & 16,7 & \\
\hline Enterobacter cloacae & 0 & 0,0 & 1 & 5,6 & \\
\hline Staphylococcus epidermidis & 0 & 0,0 & 2 & 11,0 & \\
\hline
\end{tabular}

Tabel 2 Pola Sensitivitas dan Resistensi Antibiotik pada DM-2 dengan ISK dan BAS

\begin{tabular}{|c|c|c|c|c|c|}
\hline \multirow[b]{3}{*}{ Antibiotik } & \multicolumn{4}{|c|}{ Pasien DM-2 ( $\mathrm{N}=36)$} & \multirow[b]{3}{*}{$\mathbf{P}$} \\
\hline & \multicolumn{2}{|c|}{ ISK $(\mathbf{N}=18)$} & \multicolumn{2}{|c|}{ BAS $(\mathbf{N}=18)$} & \\
\hline & Sensitif & Resisten & Sensitif & Resisten & \\
\hline Amoxyclav & $15(83,3)$ & $3(16,7)$ & $17(94,4)$ & $1(5,6)$ & 0,603 \\
\hline Amikacin & $17(94,4)$ & $1(5,6)$ & $18(100,0)$ & $0(0,0)$ & 1,000 \\
\hline Ciprofloxacin & $8(44,4)$ & $10(55,6)$ & $8(44,4)$ & $10(55,6)$ & 1,000 \\
\hline Cefotaxime & $3(16,7)$ & $15(83,3)$ & $3(16,7)$ & $15(83,3)$ & 1,000 \\
\hline Ceftriaxone & $13(72,2)$ & $5(27,8)$ & $10(55,6)$ & $8(44,4)$ & 0,298 \\
\hline Doxicycline & $14(77,8)$ & $4(22,2)$ & $11(61,1)$ & $7(38,9)$ & 0,278 \\
\hline Cefixime & $8(44,4)$ & $10(55,6)$ & $1(5,6)$ & $17(94,4)$ & 0,018 \\
\hline Meropenem & $18(100,0)$ & $0(0,0)$ & $18(100,0)$ & $0(0,0)$ & - \\
\hline Cefoperazone & $18(100,0)$ & $0(0,0)$ & $17(94,4)$ & $1(5,6)$ & 1,000 \\
\hline Tetracycline & $6(33,3)$ & $12(66,7)$ & $8(44,4)$ & $10(55,6)$ & 0,490 \\
\hline Ampicillin & $0(0,0)$ & $18(100,0)$ & $0(0,0)$ & $18(100,0)$ & - \\
\hline
\end{tabular}

asimtomatik ditemukan hasil yang sama yaitu tingkat resistensi ampicillin adalah paling tinggi 100\% $(\mathrm{n}=18)$, diikuti cefotaxime $83,3 \%(\mathrm{n}=15)$. Dari hasil pemeriksaan sensitivitas dan resistensi antibiotik dari pemeriksaan kultur urin pasien DM-2 dengan ISK dan bakteriuria asimtomatik menunjukkan bahwa tidak ditemukan perbedaan yang bermakna untuk seluruh jenis antibiotik $(p>0,05)$ kecuali cefixime $(\mathrm{P}=0.018)$ pada uji Chi-Square (Tabel 2).

\section{PEMBAHASAN}

Penelitian ini merupakan uji diagnostik pemeriksaan dengan alat Cobas U 411 sistem dengan menggunakan dipstik carik celup untuk pemeriksaan 


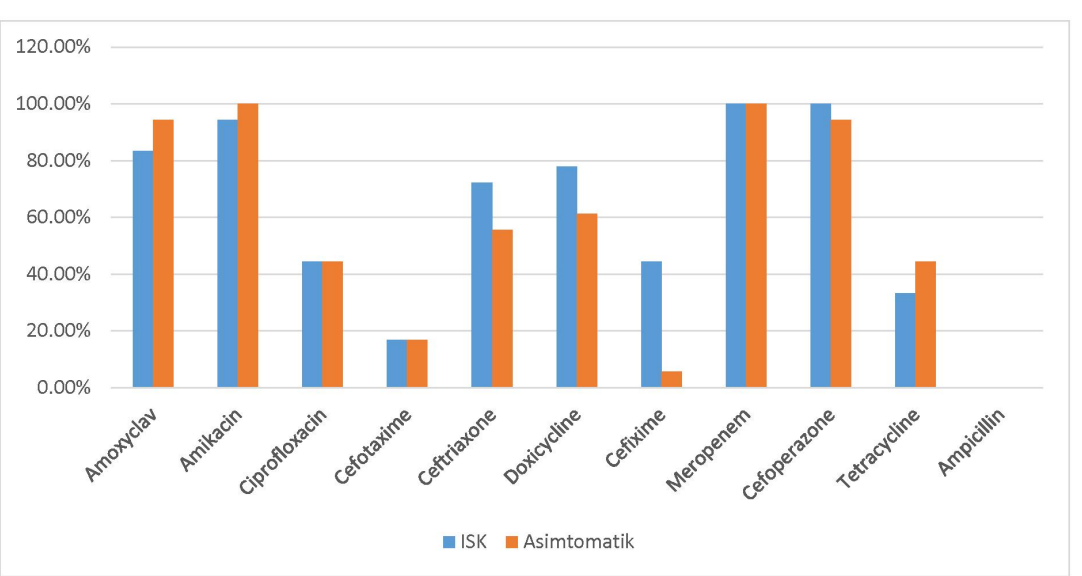

Gambar 1 Diagram antibiotik yang sensitif terhadap bakteri dari kultur urin pada pasien DM-2 dengan ISK dan bakteriuria asimtomatik

leukosit di urin dengan cepat. Pada penelitian ini dikumpulkan 36 orang dimana terbagi menjadi dua kelompok yaitu 18 orang merupakan pasien DM-2 dengan ISK dan dan 18 orang merupakan pasien dengan DM-2 dengan bakteriuria asimtomatik. Infeksi pada pasien diabetes umumnya terlokalisasi di saluran kemih. Gejala infeksi saluran kemih pada pasien diabetes umumnya asimtomatik, namun dapat berkembang menjadi simtomatik. ${ }^{11}$

Pada penelitian ini didapatkan dari pasien DM-2 dengan ISK, $14(77,8 \%)$ pasien berjenis kelamin perempuan dan jenis kelamin laki-laki ditemukan sebanyak 4 orang (22,2\%). Sedangkan dari 18 pasien DM-2 dengan bakteriuria asimtomatik ditemukan sebagian besar berjenis kelamin perempuan. Hal ini didukung oleh penelitian terdahulu oleh Jha PK et al., bahwa prevalensi infeksi saluran kemih pasien diabetes perempuan $43 \%$ lebih tinggi daripada pasien diabetes laki-laki sebanyak $10 \% .{ }^{12}$ Begitupula hasil serupa ditemukan pada penelitian Gurjar D et al., dimana penderita diabetes dengan bakteriuria asimtomatik $71,9 \%$ adalah perempuan dan $28,13 \%$ adalah laki-laki. ${ }^{13}$

Ahmed AA menemukan bahwa perempuan diabetes lebih rentan terhadap ISK dibandingkan dengan laki-laki dengan diabetes. ${ }^{14} \mathrm{Hal}$ ini dikarenakan infeksi saluran kemih lebih banyak terjadi pada pasien diabetes perempuan, karena secara anatomi uretra perempuan lebih pendek. Orifisium uretra dan vagina juga merupakan daerah yang mudah sekali terjadi kolonisasi bakteri. ${ }^{15}$ Prevalensi ISK pada pasien diabetes tiga kali lipat lebih tinggi pada wanita dibandingkan pada pria. ${ }^{16}$ Perbedaan penting ini dapat dijelaskan oleh berbagai faktor yang berhubungan dengan pria, seperti semakin panjang uretra, semakin besar jarak antara meatus urogenital dan anus, dan sifat antibakteri dari cairan prostat. ${ }^{16}$ Hal inipun sejalan dengan penelitian Girishbabu RJ et al., yang menunjukkan jumlah kasus bakteriuria asimtomatik tertinggi di antara wanita diabetes $(58,3 \%)$ bila dibandingkan dengan pria diabetes $(41,7 \%){ }^{17}$

Pada penelitian ini didapatkan bahwa pasien DM-2 dengan ISK yang termuda menderita penyakit adalah berusia 39 tahun dan tertua adalah berusia 74 tahun. Didapatkan bahwa kelompok umur pasien DM-2 dengan ISK yang paling banyak dijumpai pada kelompok umur 39 - 50 tahun yaitu sebanyak 9 orang (50\%), diikuti dengan kelompok umur 51 - 62 tahun sebanyak 5 orang $(27,8 \%)$ dan yang terendah pada kelompok umur 63 74 tahun sebanyak 4 orang $(22,2 \%)$. Hasil ini sama dengan penelitian yang dilakukan oleh Ariwijaya M dan Suwitra K sebelumnya dimana didapatkan kejadian ISK pada pasien DM-2 lebih banyak didapatkan pada umur $<50$ tahun dibandingkan dengan umur $>50$ tahun $(61,1 \%$ vs $38,9 \%) .{ }^{18}$

Hasil penelitian ini juga menunjukkan bahwa pasien DM-2 dengan bakteriuria asimtomatik paling banyak dijumpai pada kelompok umur 51 - 62 tahun, diikuti dengan kelompok umur 39 50 tahun, dan kelompok umur 63 - 74 tahun. Hasil ini sesuai dengan penelitian Bissong ME et al., yang mengemukakan bahwa mayoritas lebih banyak dalam kelompok usia 50 tahun keatas (58,5\%), sedangkan rentang usia setidaknya kurang dari 30 tahun $(18,68 \%) .{ }^{19}$ Hal inipun sejalan dengan penelitian yang dilakukan oleh Gurjar D dimana prevalensi tertinggi di antara semua kasus bakteriuria asimtomatik ditemukan pada kelompok usia $50-59$ tahun. ${ }^{13}$

Pada penelitian ini ditemukan kuman penyebab ISK pada pasien DM-2 terbanyak adalah Escherichia coli. Dari hasil penelitian ini juga ditemukan bahwa tidak ada perbedaan jenis kuman pada pasien DM-2 dengan infeksi saluran kemih dan bakteriuria asimptomatik. Hasil penelitian ini sejalan dengan penelitian Bissong ME et al., dimana gram negatif adalah tipe organisme yang paling umum $(45,1 \%)$ diisolasi dari urin, diikuti oleh gram positif $(41,2 \%)$ kemudian ragi $(13,7 \%){ }^{19}$

Penelitian Ahmed AA menemukan bahwa bakteri yang paling sering ditemukam pada DM-2 dengan ISK adalah Escherichia coli $(45,28 \%)$, kemudian Klebsiella pneumoniae (15,1\%), Staphylococcus saprophyticus $(15,1 \%) .{ }^{14} \mathrm{Hal}$ ini dikarenakan bakteri yang ada di perineum dan vagina dapat masuk ke kandung kemih dan selanjutnya naik ke ginjal dimana memicu terjadiya ISK. Langkah penting dalam patogenesis ISK adalah invasi uropatogen ke mukosa kandung kemih. Oleh karena itu, adhesions faktor virulensi penting. Meskipun faktor virulensi telah dicirikan paling baik dalam E. coli (uropatogen yang paling umum), tetapi banyak dari prinsip yang sama dapat diterapkan pada uropathogens lainnya; misalnya Klebsiella. Akan tetapi penelitian Chiţă T menemukan bakteri yang terkait dengan 
ISK sebagian besar adalah E. coli $(68,9 \%) .{ }^{20}$ Studi kasus - kontrol lain, yang dilakukan di New Delhi, India, yang mengevaluasi prevalensi ISK dan jaringan parut ginjal pada 155 pasien dengan diabetes, juga menemukan bahwa $E$. coli adalah organisme yang paling sering terlibat (64,3\%), diikuti oleh Staphylococcus aureus $(21,4 \%)$ dan Klebsiella pneumoniae $(14,3 \%) .^{21}$

Pada penelitian ini kuman penyebab bakteriuria asimptomatik terutama Escherichia coli, diikuti dengan Klebsiella pneumonia, Staphylococcus aureus, Staphylococcus saprophyticus, Serratia liquefaciens, Streptococcus agalactiae, Enterobacter cloacae, dan Staphylococcus epidermidis. Penelitian Omoregie R et al., di Nigeria telah melaporkan Staphylococcus aureus menjadi patogen yang paling umum pada penderita diabetes dan non-diabetes. ${ }^{22}$ Tingginya prevalensi Staphylococcus sp dalam bakteriuria asimtomatik mungkin disebabkan oleh fakta bahwa organisme ini sebagian besar adalah flora kulit normal dan dapat masuk ke saluran kemih selama hubungan seksual.

Penelitian Girishbabu RJ et al., menunjukkan jenis mikroorganisme pada bakteri bakteriuria asimtomatik yaitu Klebsiella pneumoniae 25 (20.9\%) dan Staphylococcus aureus 15 (12.5\%). ${ }^{17}$ Isolat bakteri telah berubah dari waktu ke waktu dan dari satu tempat ke tempat lain. Hal ini dikarenakan terdapat faktor-faktor lain seperti uretra perempuan lebih pendek, uretra dekat anus dan vagina, perubahan biologis karena menopause pada wanita dan pembesaran prostat dan neurogenik kandung kemih pada pria berkontribusi terhadap bakteriuria asimtomatik. ${ }^{17}$ Mikroorganisme yang menyebabkan bakteriuria asimtomatik pada orang dengan diabetes mellitus mirip dengan yang menyebabkan bakteriuria pada individu non-diabetes.

Penelitian Ipe DS menunjukkan bahwa bakteriuria pada diabetes sulit diberantas dan hingga $20 \%$ wanita yang tidak diobati tetap menunjukkan keberadaan bakteriuria secara jangka panjang. ${ }^{23}$ Pada wanita dengan DM-2 dan memiliki bakteriuria berhubungan dengan insidensi ISK dan urosepsis yang lebih tinggi. Namun, penelitian belum menunjukkan peningkatan insidensi kerusakan ginjal jangka panjang. Staphylococcus dan Enterococcus juga ditemukan dalam proporsi yang bermakna dimana pada kasus ini Staphylococcus ditemukan pada $18,75 \%$ pada kasus bakteriuria asimtomatik.

Pada penelitian ini didapatkan hasil uji sensitivitas terhadap kultur urin 18 pasien DM-2 dengan ISK ditemukan bahwa tingkat sensitivitas meropenem dan cefoperazone adalah paling tinggi. Dari penelitian ini juga didapatkan hasil uji sensitivitas terhadap kultur urin 18 pasien DM-2 dengan bakteriuria asimtomatik, ditemukan bahwa tingkat sensitivitas amikacin dan meropenem adalah paling tinggi, diikuti amoxyclav dan cefoperazone. Hasil penelitian tersebut sejalan dengan studi yang dilakukan oleh Girishbabu RJ et al. dimana menunjukkan pasien DM-2 dengan bakteriuria asimtomatik sensitif terhadap amikacin $(85,0 \%)$ dan ciprofloxacin $(68,0 \%) .{ }^{17}$ Sensitivitas antimikroba dan pola resistensi bervariasi dari komunitas ke komunitas dan dari rumah sakit ke rumah sakit. Ini karena munculnya strain yang resisten akibat penggunaan antibiotik secara sembarangan. Dari hasil kultur urin 18 pasien DM-2 dengan ISK dan 18 pasien DM-2 dengan bakteriuria asimtomatik ditemukan tingkat resistensi ampicillin adalah paling tinggi diikuti cefotaxime. Dalam penelitian Girishbabu RJ et al., isolat kultur urin pasien DM-2 dengan ISK menunjukkan sensitivitas $100,0 \%$ terhadap imipenem, amikacin (85,0\%), dan ciprofloxacin (68,0\%). Ampicillin ditemukan paling tidak sensitif $(18,0 \%){ }^{17}$

Namun, kekhawatiran klinis pentingnya bakteriuria asimtomatik pada individu diabetes adalah kontribusinya terhadap morbiditas, baik risiko jangka pendek yaitu infeksi saluran kemih dan komplikasi yang lebih serius atau risiko jangka panjang berkembang menjadi komplikasi diabetes serius (misalnya, nefropati). Pasien dengan bakteriuria tidak diobati dengan antibiotik apa pun. Identifikasi dan pengobatan bakteriuria asimtomatik akan tepat jika hal itu mencegah infeksi simptomatik, terutama pielonefritis atau komplikasi infeksi saluran kemih pada diabetes. Terapi antimikroba untuk bakteriuria asimtomatik juga bermanfaat pada beberapa populasi pasien seperti wanita hamil dan individu yang menjalani intervensi genitourinari traumatik. Tidak banyak studi kontrol acak yang dilakukan untuk menentukan keampuhan mengobati bakteriuria asimtomatik pada individu diabetes untuk mencegah terjadinya komplikasi dan dilema pengobatan dibandingkan tidak memperlakukan pasien dengan bakteriuria berlanjut. ${ }^{24}$

Berbagai faktor risiko bakteriuria asimtomatik pada wanita dengan diabetes termasuk usia, durasi penyakit, mikroangiopati ginjal (proteinuria, albuminuria), ISK pada tahun sebelumnya, aktivitas seksual, indeks massa tubuh yang lebih rendah dan status komplikasi diabetes (retinopati, nefropati dan neuropati). ${ }^{24}$

\section{SIMPULAN}

Kuman penyebab ISK pada pasien DM-2 terbanyak adalah Escherichia coli, dimana pada infeksi bakteri yang bersifat asimtomatik didominasi oleh jenis bakteri Escherichia coli, Klebsiella pneumoniae, Staphylococcus aureus, dan Streptococcus agalactiae. ISK dan bakteriuria asimtomatik lebih banyak ditemukan pada pasien perempuan dengan DM-2 daripada laki-laki dengan DM-2. Hasil uji sensitivitas 
antibiotik terhadap kultur urin pasien DM-2 dengan ISK maupun pada pasien DM-2 dengan bakteriuria asimtomatik ditemukan bahwa tingkat sensitivitas antibiotik paling tinggi adalah meropenem dan ampicillin adalah antibiotik paling resisten pada ISK yang terjadi pada kedua kelompok. Berkaitan dengan hasil tersebut maka ketika seorang dokter memutuskan untuk meresepkan antibiotik kepada pasien DM-2 dengan ISK, sebaiknya dilakukan tes kepekaan antibiotik terlebih dahulu untuk mendapatkan terapi yang tepat dan mencegah resisitensi antibiotik.

\section{KONFLIK KEPENTINGAN}

Tidak terdapat konflik kepentingan dalam penulisan laporan penelitian ini.

\section{ETIKA PENELITIAN}

Penelitian ini dilaksanakan setelah mendapat izin dari Komite Etik Penelitian Kesehatan Fakultas Kedokteran Universitas Sumatera Utara, Medan, Indonesia.

\section{PENDANAAN}

Peneliti bertanggung jawab penuh terhadap pendanaan penelitian ini tanpa melibatkan pihak sponsor, beasiswa, atau sumber pendanaan lainnya.

\section{KONTRIBUSI PENULIS}

Seluruh penulis berkontribusi aktif dalam penyusunan laporan penelitian ini baik dari tahap pembuatan kerangka konsep, pengumpulan data, analisis data, hingga interpretasi data penelitian.

\section{DAFTAR PUSTAKA}

1. Nitzan O, Elias M, Chazan B, Saliba W. Urinary tract infections in patients with type 2 diabetes mellitus: review of prevalence, diagnosis, and management. Diabetes Metab Syndr Obes. 2015;8:129-136. Published 2015 Feb 26. doi: 10.2147/DMSO.S51792.

2. Longdoh NA, Assob JCN, Nsagha SD, Nde PF, Kamga HLF, Nkume AF, et al. Urophatogens from Diabetic Patients with Asymptomatic Bacteriuria and Urinary Tract Infections. The West London Medical Journal. 2013;5(1):7-14.

3. Zheng Y, Ley SH, Hu FB. Global aetiology and epidemiology of type 2 diabetes mellitus and its complications. Nat Rev Endocrinol. 2018;14(2):88-98.

4. Aguayo-Mazzucato C, Diaque P, Hernandez S, Rosas S, Kostic A, Caballero AE. Understanding the growing epidemic of type 2 diabetes in the Hispanic population living in the United States. Diabetes Metab Res Rev. 2019;35(2):e3097.

5. Carey IM, Critchley JA, DeWilde S, Harris T, Hosking FJ, Cook DG. Risk of Infection in Type 1 and Type 2 Diabetes Compared With the General Population: A Matched Cohort Study. Diabetes Care. 2018;41(3):513-521.

6. Joshi N, Caputo GM, Weitekamp MR, Karchmer AW. Infections in patients with diabetes mellitus. N Engl J Med. 1999;341(25):1906-1912.
7. Harding GK, Zhanel GG, Nicolle LE, Cheang M; Manitoba Diabetes Urinary Tract Infection Study Group. Antimicrobial treatment in diabetic women with asymptomatic bacteriuria. NEnglJMed. 2002;347(20):1576-1583.

8. Warren JW, Brown V, Jacobs S, Horne L, Langenberg P, Greenberg P. Urinary tract infection and inflammation at onset of interstitial cystitis/painful bladder syndrome. Urology. 2008;71(6):1085-1090.

9. Flores-Mireles AL, Walker JN, Caparon M, Hultgren SJ. Urinary tract infections: epidemiology, mechanisms of infection and treatment options. Nat Rev Microbiol. 2015;13(5):269-284.

10. Schmiemann G, Kniehl E, Gebhardt K, Matejczyk MM, Hummers-Pradier E. The diagnosis of urinary tract infection: a systematic review. Dtsch Arztebl Int. 2010;107(21):361-367.

11. Saleem M, Daniel B. Prevalence of urinary tract infection among patients with diabetes in Bangalore City. Int J Emerg Sci. 2011;1(2):133-142.

12. Jha PK, Baral R, Khanal B. Prevalence of Uropathogens in Diabetic Patient and Their Susceptibility Pattern at a tertiery Care Center in Nepal-A Retrospective Study. Internal Journal of Biomedical Laboratory Science (IJBLS). 2014;3(2):29-34

13. Gurjar D, Mathur A, Sai R, Lakesar A, Saxena P. Asymptomatic Bacteriuria and Its Associated Factors in Type II Diabetes Mellitus. Int J Adv Med. 2017;4(6):1633-1637.

14. Ahmed AA. Prevalence of urinary tract infection in diabetic patients and identification of the causal microorganisms. Zanco J Med Sci. 2013;17(1):363-369.

15. Colleen S, Myhrberg H, Mårdh PA. Bacterial colonization of human urethral mucosa. I. Scanning electron microscopy. Scand J Urol Nephrol. 1980;14(1):9-15.

16. Geerlings SE. Urinary tract infections in patients with diabetes mellitus: epidemiology, pathogenesis and treatment. Int J Antimicrob Agents. 2008;31 Suppl 1:S54-S57.

17. Girishbabu RJ, Prakash R, Prashanth HV, Chandrasekar SC. Asymptomatic Bacteriuria in Patients with Diabetes Mellitus. National Journal of Laboratory Medicine. 2013;2(2):11-13

18. Ariwijaya M, Suwitra K. Prevalensi, Karakteristik dan Faktor - faktor yang Terkait dengan ISK pada Penderita DM-2 yang Rawat Inap. Jurnal Penyakit Dalam. 2007;8(2):112-127.

19. Bissong ME, Fon PN, Tabe-Besong FO, Akenji TN. Asymptomatic bacteriuria in diabetes mellitus patients in Southwest Cameroon. Afr Health Sci. 2013;13(3):661-666.

20. Chiţă T, Timar B, Muntean D, Bădiţoiu L, Horhat F, Hogea E, et al. Urinary tract infections in Romanian patients with diabetes: prevalence, etiology, and risk factors. Ther Clin Risk Manag. 2016;13:1-7.

21. Goswami R, Bal CS, Tejaswi S, Punjabi GV, Kapil A, Kochupillai N. Prevalence of urinary tract infection and renal scars in patients with diabetes mellitus. Diabetes Res Clin Pract. 2001;53(3):181-186.

22. Omoregie R, Erebor JO,Ahonkhai I, Isibor JO, Ogefere HO. Observed changes in the prevalence of uropathogens in Benin City, Nigeria. N Z J Med Lab Sci. 2008;62:29-31.

23. Ipe DS, Sundac L, Benjamin WH Jr, Moore KH, Ulett GC. Asymptomatic bacteriuria: prevalence rates of causal microorganisms, etiology of infection in different patient populations, and recent advances in molecular detection. FEMS Microbiol Lett. 2013;346(1):1-10.

24. Vishwanath S, Sarda R, D’Souza AO, Mukhopadhyay C. Asymptomatic Bacteriuria among Patients with Diabetes Mellitus at a Tertiary Care Center. National Journal of Laboratory Medicine. 2013;2(3):16-19.

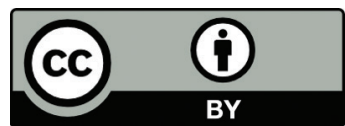

This work is licensed under a Creative Commons Attribution 